\title{
Pharmaceutical and Biotechnological Importance of Actinobacterial Products
}

\author{
Krishnamoorthy Bhakyashree, Krishnan Kannabiran* \\ Department of Biomedical Sciences, School of Biosciences and Technology, Vellore Institute of Technology, Vellore, Tamil Nadu, INDIA.
}

\begin{abstract}
Many compounds produced by marine microbes possess significant pharmaceutical applications. Actinobacteria are one among the microbes producing a variety of antibiotics. Apart from antibiotics, it also produces many novel enzymes and important pharmaceutical products. Actinobacteria serves as a reservoir of antibiotics and novel chemical compounds and it contributes $80 \%$ of antibiotics available in the market. It was continuously been explored for novel bioactive compounds and new chemical entities. Many of them are more promising against microbial pathogens and even drug resistant pathogens. Apart from antibiotics, many enzymes are also produced by actinobacteria. The usage of enzymes in diverse pharmaceutical and biotechnological industries is gaining momentum and moreover, there is a growing demand for the discovery of novel metabolites and enzymes to fulfill the requirement of pharmaceutical industry. Apart from all these products actinobacteria also produces biosurfactants. Members of actinobactaerial genera have been extensively used in the removal of toxic dyes and other toxic pollutants. In this review, the up to date information available on the pharmaceutical and biotechnological uses of actinobacterial products and the scope for screening of actinobacterial genome for production of novel compounds for pharmaceutical applications have been discussed.
\end{abstract}

Key words: Actinobacteria, Metabolites, Antibiotics, Enzymes, Biosurfactants, Dye degradation.

\section{INTRODUCTION}

Actinobacteria are Gram-positive bacteria with high $\mathrm{G}+\mathrm{C}$ content, produces various compounds such as antibiotics, biosurfactants,immunemodifiers, probiotics, enzymes and enzyme inhibitors (Figure 1) which are useful in pharmaceutical, textile, paper, food, leather and detergent industries. ${ }^{1}$ Actinobacteria are found in various natural habitats like soil, water, freshwater, ponds, lakes, industrial effluents, waste water and in marine environment ${ }^{2}$ Actinobacteria grow on adverse environments are useful in decomposition of organic matter. ${ }^{3}$ Actinobacteria derived from both marine and terrestrial environments are known to produce several bioactive compounds with potential pharmaceutical applications. Actinobacteria derived secondary metabolites are proved to be very effective in inhibiting bacterial biofilm formation. ${ }^{4}$ Bacterial biofilm confers protection to antibiotic treatment. Few of them are rare strains due to their poor growth rate, they are Actinoplanes, Microbispora, Micromonospora, Dactylosporangiu and Kineospora. ${ }^{5}$

Actinobacteria are valuable prokaryotes considered as the richest source for several natural products of commercial interest and nearly half of the compounds available in the market are from actinobacteria. ${ }^{6}$ Marine microorganisms especially actinobacteria are involved in the degradation of dead plankton, plants and animals which helps in cleaning of the environment clean for the survival of other macroorganisms. Several new compound of pharmacological and industrially importance was reported from actinobacteria isolated from
Submission Date: 16-12-2019; Revision Date: 17-05-2020; Accepted Date: 09-09-2020

DOI: 10.5530/ijper.54.4.178 Correspondence: Prof. Krishnan Kannabiran Senior Professor, Department of Biomedical Sciences, School of Biosciences and Technology, Vellore Institute of Technology, Vellore 632014, Tamil Nadu, INDIA Phone no: +91-04162202496

Email id: kkb@vit.ac.in

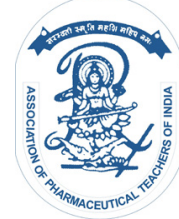

www.ijper.org 


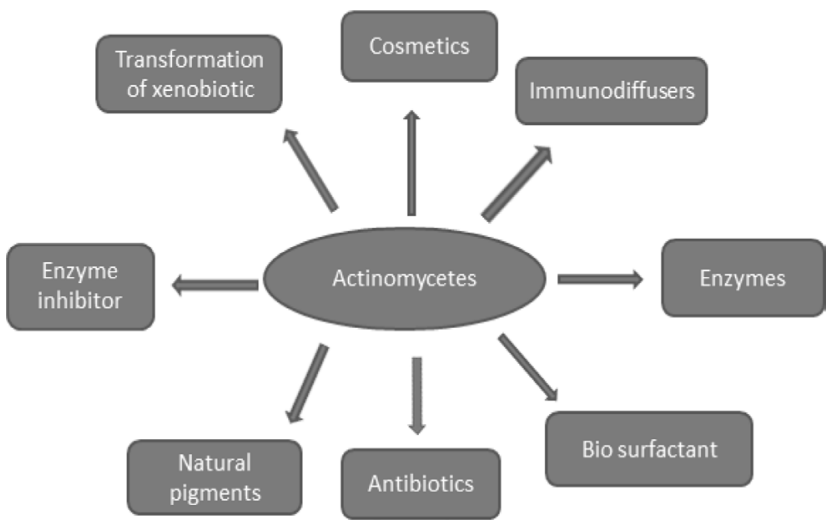

Figure 1: Pharmaceutical and biotechnological applications of actinobacteria.

marine, unexplored regions and wet land. Many actinomycetes produce several enzymes like peptidase, xylanase, lignilase, amylase, pectinase, hemicellulase and keratinase. $^{7}$ Production of these enzymes by actinobacteria enables them to degrade the organic matter found in the marine environment. ${ }^{8}$ This paper mainly focuses the pharmaceutical value of actinobacterial derived secondary metabolites.

\section{Pharmaceutical applications of actinobacteria}

Actinobacteria is considered as a major producer of antibiotics $^{1}$ (Table 1). Most of the commercially available antibiotics are derived from the group Streptomyces. It also produces a variety of secondary metabolites of pharmaceutical importance. ${ }^{9,10}$ Actinobacteria also synthesize various enzyme inhibitors of low molecular weight compounds used in cancer treatment. Rrevistin, an enzyme derived from Streptomyces species plays a significant role in inhibiting reverse transcriptase and alistragin from Streptomyces roseoviridis found a role in inhibiting carboxypeptidase. ${ }^{11}$ Streptomyces tsukubaensis sp. produces immunomodifiers FR-900506 showed inhibitory activity against interleukin-2 production, mixed lymphocyte reaction, interferon and cytotoxic- $T$ cells. $^{12}$ Actinomycetes derived antimicrobial, antiinsecticide; anticancer, anti-parasitic compounds have wide range of applications in numerous pharmaceutical industries.

\section{Enzymes from actinobacteria}

Actinobacteria produces several enzymes with diverse activities which help in the process of mineralization of organic matter and also help in canalization of various biochemical reactions. Production of various enzymes such as L-glutaminase, $\alpha$-galactosidase, amylase, cellulase, protease, L-asparaginase was reported from marine actinobacteria. ${ }^{13}$ Amylases hydrolyze starch molecule to give various products like dextrins and

\begin{tabular}{|c|c|c|}
\hline Antibiotic Name & Actinobacteria & References \\
\hline Streptomycin & Streptomyces griseus & 49 \\
\hline Neomycin, Tylosin A & Streptomyces fradiae & 50 \\
\hline Kanamycin & $\begin{array}{l}\text { Streptomyces } \\
\text { kanamyceticus }\end{array}$ & 51 \\
\hline Erythromycin A & Streptomyces erythraea & 52 \\
\hline Oleandomycin & Streptomyces antibioticus & 53 \\
\hline Spiramycin & Streptomyces ambofaciens & 54 \\
\hline Monensin A & $\begin{array}{l}\text { Streptomyces } \\
\text { cinnamonensis }\end{array}$ & 55 \\
\hline Tiacumicin B & $\begin{array}{l}\text { Dactylosporangium } \\
\text { aurantiacum sub sp. } \\
\text { hamdenensis }\end{array}$ & 56 \\
\hline Rifamycin SV & Amycolatopsis mediterranei & 57 \\
\hline Kanglemycin A & $\begin{array}{c}\text { Nocardia mediterranei var. } \\
\text { kanglensis }\end{array}$ & 58 \\
\hline Oxytetracycline & Streptomyces rimosus & 59 \\
\hline Chlortetracycline & Streptomyces aureofaciens & 60 \\
\hline $\begin{array}{l}\text { Pristinamycin IA/IIA } \\
\text { (PIA and PIIA) }\end{array}$ & $\begin{array}{l}\text { Streptomyces } \\
\text { pristinaespiralis }\end{array}$ & 61 \\
\hline Fattiviracins & Streptomyces microflavus & 62 \\
\hline Lomofungin & Streptomyces lomondensis & 63 \\
\hline Actinomycin D & Streptomyces chrysomallus & 64 \\
\hline Oxanosine & $\begin{array}{c}\text { Streptomyces capreolus } \\
\text { MG265-CF3 }\end{array}$ & 65 \\
\hline Nanchangmycin & $\begin{array}{l}\text { Streptomyces } \\
\text { nanchangensis }\end{array}$ & 66 \\
\hline Kenalactams A-E & Nocardiopsis CG3 & 67 \\
\hline Nystatin A1 & Streptomyces noursei & 68 \\
\hline Nystatin-BSG005 & $\begin{array}{c}\text { Streptomyces noursei } \\
\text { GG5073SP }\end{array}$ & 69 \\
\hline Amphotericin B & Streptomyces nodosus & 70 \\
\hline Natamycin & Streptomyces natalensis & 71 \\
\hline
\end{tabular}

smaller polymers consist of glucose unit. Several thermo stable actinobacteria including Thermomonospora and Thermoactinomycetes are the biggest producers of amylases. Cellulase is another group of hydrolytic enzymes used in detergents, color extraction from juices, biostoning of jeans, pretreatment of biomass containing cellulose to improve the nutritional quality of forage. ${ }^{14}$ Two groups of extracellular amylases namely $\alpha$-amylase and glucoamylase are reported from actinobacteria. ${ }^{15}$ These amylase containing detergents were used for washing clothes at a lower temperature. ${ }^{16}$ Production of $\alpha$-amylase by Streptomyces sp. SBU3 has already been reported. ${ }^{17}$

Organisms like Thermobifida fusca and Acidothermophillus cellulolyticus are useful in biofuel industry. ${ }^{18}$ The enzyme lipase has several applications in food, chemical, 
Table 2: Industrially important enzymes from actinobacteria.

\begin{tabular}{|c|c|c|c|}
\hline Microbes & Enzymes & Applications & References \\
\hline Streptomyces & Amylase & Food and beverage industries & 35 \\
\hline Streptomyces & Protease & Leather, photographic and detergent industries & 28 \\
\hline Nocardiopsis albus sub sp. prasina OPC-131 & Chitinase & Sea food industry & 36 \\
\hline Streptomyces & Pectinase & Fruit and vegetable processing industry & 36 \\
\hline $\begin{array}{c}\text { Streptomyces purpeofuscus } \\
\text { Streptomyces albidoflavus }\end{array}$ & Xylanase & Pulp and paper industry & 37 \\
\hline Streptomyces griseorubens & Cellulase & Biofuel industry & 38 \\
\hline
\end{tabular}

\begin{tabular}{|c|c|c|c|}
\hline Actinomycetes & Product & Applications & References \\
\hline Streptomyces sp.VITDDK3 & Biosurfactant & Textile industry & 72 \\
\hline Streptomyces sp. & Probitotic & Aquaculture industry & 60 \\
\hline Streptomyces sp. NK458 & Enzyme (Dextranase) & Food industry & 73 \\
\hline Thermobifida fusca BCRC 19214 & Enzyme (Laccase) & Hair coloring agent & 74 \\
\hline Kocuriarosea HN01 & Compound & Agriculture & 75 \\
\hline Actinomadura keratinilytica strain Cpt29 & Enzyme (Keratinase) & Leather industry & 76 \\
\hline Pseudonocardia thermophila JCM3095 & Enzyme (Nitrile hydratase) & Acrylamide production & 34 \\
\hline Streptomyces sp. strain $\mathrm{AH} 4$ & Enzyme & Detergent industries & 47 \\
\hline Actinomycetes nocardiopsis A17 & Biosurfactant & Pharmaceutical and cosmetics industry & 77 \\
\hline Streptomyces griseoaurantiacus & Enzyme (cellulase) & Biodegradation & 78 \\
\hline
\end{tabular}

pharmaceutical and detergent industries. Microbial lipases are well known for its stability, selectivity and broad spectrum specificity which play a vital role in several biotechnological industries for the synthesis of biopolymers and biodiesel. ${ }^{19}$ Protease is another group of enzyme produced from micro-organisms for industrial use. ${ }^{20}$ More than $60 \%$ of the proteases are produced from micro-organisms and used for commercial applications, which include toothpastes for its antiplaque activity and antitartar cosmetics and recovery of silver from the used X-ray films. ${ }^{21}$ Enzymes produced by actinomycetes are used in lignocellulose degradation in the pulp and paper industries and textile industries. Alkaline protease production by Thermoactinomyces sp. RS1 has already been reported. ${ }^{22}$ Potential cellulolytic acidothermophilic actinobacterium DSK59 isolated from banyan tree finds potential application in bio refinery processes and the cellulase from the isolate hydrolyze sorghum biomass. ${ }^{23}$ Other industrially important enzymes such as dextran's, nitrile hydrates, lactase and carbon monoxide dehydrogenasemes are also isolated from Streptomyces sp, Psendonocardia thermophila and Thermobifida fusca. The enzyme laccase produced by Thermobifida fusca are used as a hair coloring agent. ${ }^{24}$ Martinez and his coworkers immobilized thermo stable nitrile hydrates produced by Pseudonocardia thermophila in the gel matrix for acrylamide production. ${ }^{25}$ Fibrinolytic protease activity (blood clot lysis) by Streptomyces radiopugnans VITSD8 has been reported recently. ${ }^{26}$ Important enzymes produced by actinobcteria are given in Table 2 .

\section{Biosurfactants from actinobacteria}

Products derived from actinobacteria are given in Table 3. Surfactants are important chemical products used in soaps and detergents. Production of bio surfactants from microbial sources like yeast, actinobacteria and bacteria ${ }^{27}$ and its applications in a wide variety of fields like agriculture, cosmetics, pharmaceuticals, detergents, food processing, textile manufacture and paint industries ${ }^{28,29}$ have been reported. Bio surfactants produced from actinobacteria serves as an alternatives for synthetic surfactants used in many industries, for environmental applications like enhanced oil recovery, lubrication, bioremediation, crude oil drilling, foaming, wetting, dispersion and solubilisation. ${ }^{30}$ Marine sponge derived micro-organism have gained an intense importance for the production of bio surfactants and metabolites for their high stability and biochemical accessibility. ${ }^{31}$ It was reported that bio surfactants display important biological activities including antimicrobial, insecticidal, immune modulation and antitumor activities. ${ }^{32}$ Production of lipopeptide bio surfactant from marine sponge, Dendrilla nigra derived actinobacteria, Brevibacterium aureum 
MSA 13 has been reported. ${ }^{33,34}$ Recently extraction of lipid based bio surfactant produced by Actinomycetes nocardiopsis (strain A17) has been reported. It serves as a chemical surfactant source for use in pharmaceutics and cosmetics. ${ }^{35}$ Trehalose, a lipid biosurfactant produced by rare actinobacteria, Rhodococcus species and Mycobacteria species. ${ }^{36}$

\section{Dye degradation by actinobacteria}

Biodegradation of azo dyes is economical and highly environment friendly which is applicable for the control of environment pollution caused by growth of industries leading to adverse effect on human health and ecology. ${ }^{37}$ Effluents from the textile industries include dyes, heavy metals, detergents, grease, oil and other inorganic salts. The textile dye effluents are very hard to degrade due to its color, $\mathrm{pH}$, high temperature, high Chemical Oxygen Demand (COD). ${ }^{38}$ Azo dyes are the most used dyes in textile industries compared to natural dyes due to its variety in color. ${ }^{39}$ Physical and chemical methods of removing dyes will eventually lead to large amount of sludge's causing environmental pollution. Microorganisms play a significant role in converting toxic compounds into normal harmless products such as carbon dioxide and water. Bioremediation through microorganisms is a cost effective and environmental friendly. ${ }^{40}$ Actinobacteria degrades chemical dyes easily in 8 to 10 days. Combination of two organisms will be highly effective in dye degradation rather than using one organism. ${ }^{41}$ The microbial discoloration of azo dyes leads to formation of colorless aromatic amines by reductive cleavage of azo linkage under anaerobic conditions. Under aerobic condition biodegradation of simple sulfonated amino-benzane and amino-naphthalene compounds is very simple and effective. ${ }^{42}$ However, the genus Streptomyces was considered as the best source for degradation of several azo dyes in textile as well as in detergent industries. Actinobacteria A and B degrade reactive yellow dye by using lignolytic enzymes such as lignin peroxidase, laccase and tyrosinase produced at static condition. ${ }^{43}$ A novel lignin peroxidase from Streptomyces griseosporeus SN9 can be useful in various biotechnological processes like detergent formulations and textile dye-distaining. ${ }^{44}$ Touioui et al. 2015 reported two alkaline serine proteases (SAPS-P1 and SAPS-P2) produced by Streptomyces sp. strain AH4 and suggested it can be a good source for application in laundry as detergents for its high stability and compatibility with commercial liquid and solid laundry detergents. ${ }^{45}$ Extracellular alkaline protease from Streptomyces koyangensis strain TN650 (STAP) showed high stability and compatibility with a variety of commercialized detergents and laundry detergent formulations. ${ }^{46}$ Effluents from tanneries and fertilizer industries enter into nearby river and streams causing health hazards to the humans. Azo dyes are the predominant dye which is been highly used in textile, food, paper and leather industries which is highly toxic and carcinogenic in nature. Actinobacterial species are extensively used to degrade the azo dyes from industries. ${ }^{47}$ Nocardia strains are involved in the transformation of xenobiotics. It plays a key role in degradation of organic pollutants present in soil and water. Nocardia degrade aromatic hydrocarbons by hydroxylation. Degradation of dalapon 2, 2-dichloropropionic acid (herbicide) by Nocardia species was already been reported. ${ }^{48}$

\section{CONCLUSION}

Actinobacteria serves as a 'treasure trove' of new natural product antibiotics. Actinobacteria and members of its genera play a very important role in not only production antimicrobial metabolites and antibiotics but also produces several industrially important products like enzymes, drugs, natural pigments, bio surfactants, bio remediating agents. Actinobacteria being the efficient producers of bioactive metabolites and enzymes could be exploited further for the production of new anti biotics, pharmaceutical and biotechnological products. Although, a great work has been carried out on actino bacterial genera, more comprehensive studies are still needed to exploit the potential of actinomycetes. Genome mining of actinobacteria would certainly help to identify the potential stains based on polyketide synthase (PKS) and non-ribosomal polyketide synthases (NRPSs) genes encoded for novel compounds of pharmaceutical value. This not only fulfills the needs of the pharmaceutical industry in making new drugs but also help in human health and well being.

\section{ACKNOWLEDGEMENT}

The authors would like to thank the management of Vellore Institute of Technology for encouraging us to write this review.

\section{CONFLICT OF INTEREST}

The authors report no conflict of interest.

\section{ABBREVIATIONS}

G+C: Guanine+ Cytosine; COD: Chemical Oxygen Demand; PKS: Polyketide synthase; NRPSs: Nonribosomal polyketide synthases. 


\section{REFERENCES}

1. Collins $\mathrm{CH}$, Lyne PM, Grange JM. "Microbiological methods" $7^{\text {th }}$ ed. Butterworth Heinemann Ltd, London. 1995;1-465.

2. Chandramohan D. Coastal microbial process: Coastal zone management (In Tamilnadu state, India). Ocean Data Centre, Anna University, Madras. 1991;93.

3. Adegboye MF, Babalola OO. Taxonomy and ecology of antibiotic producing actinomycetes. Afr J Agric Res. 2012;7(15):2255-61.

4. Azman AS, Mawang C, Khairat JE, AbuBakar S. Actinobacteria-a promising natural source of anti-biofilm agents. Int Microbiol. 2019;22:403-9.

5. Hayakawa M. Studies on the isolation and distribution of rare actinomycetes in soil. Actinomycetologica. 2008;22(1):12-9.

6. Jayaprakashvel $M$. Therapeutically active biomolecules from marine actinomycetes. J Mod Biotechnol. 2012;1(1):1-7.

7. Macagnan D, Romeiro RD, Pomella AW, DeSouza JT. Production of lytic enzymes and siderophores and inhibition of germination of basidiospores of Moniliophthora (ex Crinipellis) perniciosa by phylloplane actinomycetes. Biol Control. 2008;47(3):309-14.

8. Marsh P, Wellington EMH. Molecular ecology of filamentous actinomycetes in soil. Molecular Ecology of Rhizosphere Microorganisms, Wiley- $\mathrm{VCH}$ Verlag GmbH. 2007;133-49.

9. Valdés M, Pérez NO, Estrada-De Los SP, Caballero-Mellado J, PeñaCabriales JJ, et al. Non-Frankia actinomycetes isolated from surfacesterilized roots of Casuarina equisetifolia fix nitrogen. Appl Environ Microbiol. 2005;71(1):460-6

10. Gtari M, Ghodhbane-Gtari F, Nouioui I, Beauchemin N, Tisa LS. Phylogenetic perspectives of nitrogen-fixing actinobacteria. Arch Microbiol. 2012;194(1):3-11.

11. Habbeche A, Saoudi B, Jaouadi B, Haberra S, Kerouaz B, Boudelaa M, et al. Purification and biochemical characterization of a detergent-stable keratinase from a newly thermophilic actinomycete Actinomadura keratinilytica strain Cpt29 isolated from poultry compost. J Biosci Bioeng. 2014;117(4):413-21.

12. Keller U, Lang M, Crnovcic I, Pfennig F, Schauwecker F. The actinomycin biosynthetic gene cluster of Streptomyces chrysomallus: A genetic hall of mirrors for synthesis of a molecule with mirror symmetry. J Bacteriol. 2010;192(10):2583-95

13. Lakshmanaperumalsamy $P$. Studies on actinomycetes with special reference to antagonistic Streptomycetes from sediments of Porto Novo coastal zone Ph. D. thesis, Annamalai University, India.1978;192.

14. Zhou L, Yeung K, Yuen C. Combined cellulase and wrinkle free treatment on cotton fabric. J Dong Hua University. 2001;18(1):11-5.

15. Shanmughapriya S, Kiran GS, Selvin J, Gandhimathi R, Baskar TB, Manilal A, et al. Optimization, production and partial characterization of an alkalophilic amylase produced by sponge associated marine bacterium Halobacterium salinarum MMD047. Biotechnol Bioproc E. 2009;14(1):67-75.

16. Chakraborty S, Raut G, Khopade A, Mahadik K, Kokare C. Study on calcium ion independent $\alpha$-amylase from haloalkaliphilic marine Streptomyces strain A3. Indian J Biotechnol. 2012;11;427-37.

17. Krishnakumar S, Bai V, Premkumar J. Production of alpha amylase by salttolerant actinomycete Streptomyces sp.-SBU3 isolated from marine sponge. Indian J Geo Mar Sci. 2015;44:1-6.

18. Kim YJ, Kim DO, Chun OK, Shin DH, Jung $\mathrm{H}$, Lee $\mathrm{CY}$, et al. Phenolic extraction from apple peel by cellulases from Thermobifida fusca. J Agr Food Chem. 2005;53(24):9560-5.

19. Jaeger KE, Eggert T. Lipase for biotechnology. Curr Opin Biotechnol. 2002;13:390- 7.

20. Ribitsch D, Karl W, Birner-Grünberger R, Gruber K, Eiteljörg I, Remler P, et al. C-terminal truncation of a metagenome-derived detergent protease for effective expression in E. coli. J Biotechnol. 2010;150(3):408-16.

21. Gohel SD, Singh SP. Purification strategies, characteristics and thermodynamic analysis of a highly thermostable alkaline protease from a salt-tolerant alkaliphilic actinomycete, Nocardiopsis alba OK-5. J Chromatogr B. 2012;889:61-8

22. Verma A, Ansari MW, Anwar MS, Agrawal R, Agrawal S. Alkaline protease from Thermoactinomyces sp. RS1 mitigates industrial pollution. Protoplasma. 2014;251(3):711-8.

23. Budihal SR, Agsar D, Patil SR. Enhanced production and application of acidothermophilic Streptomyces cellulase. Bioresour Technol. 2016;200:706-12.
24. Chen CY, Huang YC, Wei CM, Meng M, Liu WH, Yang CH. Properties of the newly isolated extracellular thermo-alkali-stable laccase from thermophilic actinomycetes, Thermobifida fusca and its application in dye intermediates oxidation. AMB Express. 2013;3(1):49.

25. Martinez S, Kuhn ML, Russell JT, Holz RC, Elgren TE. Acrylamide production using encapsulated nitrile hydratase from Pseudonocardia thermophila in a sol-gel matrix. J Mol Catal . 2014;100:19-24.

26. Dhamodharan $D$, Naine J. Novel fibrinolytic protease producing Streptomyces radiopugnans VITSD8 from marine sponges. Mar Drugs. 2019;17(3):164.

27. Pirôllo MP, Mariano AP, Lovaglio RB, Costa SG, Walter V, Hausmann R, et al. Biosurfactant synthesis by Pseudomonas aeruginosa LBI isolated from a hydrocarbon-contaminated site. J Appl Microbiol. 2008;105(5):1484-90.

28. Desai JD, Banat IM. Microbial production of surfactants and their commercial potential. Microbiol Mol Biol Rev. 1997;61(1):47-64.

29. Shavandi M, Mohebali G, Haddadi A, Shakarami H, Nuhi A. Emulsification potential of a newly isolated biosurfactant-producing bacterium, Rhodococcus sp. strain TA6. Colloids Surf B Biointerfaces. 2011;82(2):477-82.

30. Singh A, Hamme JDV, Ward OP. Surfactants in microbiology and biotechnology: Part 2. Application aspects. Biotechnol Adv. 2007;25(1):99-121.

31. Skariyachan SG, Rao A, Patil MR, Saikia B, Bharadwaj KV, Rao GSJ. Antimicrobial potential of metabolites extracted from bacterial symbionts associated with marine sponges in coastal area of Gulf of Mannar Biosphere, India. Lett Appl Microbiol. 2014;58(3):231-41.

32. Liang TW, Wu CC, Cheng WT, Chen YC, Wang CL, Wang IL, et al. Exopolysaccharides and antimicrobial biosurfactants produced by Paenibacillus macerans TKU029. Appl Bioche Biotechnol. 2014;172(2):933-50.

33. Gandhimathi R, Arunkumar M, Selvin J, Thangavelu T, Sivaramakrishnan S, Kiran GS, et al. Antimicrobial potential of sponge associated marine actinomycetes. J Mycol Med. 2008;18(1):16-22.

34. Kiran GS, Thomas TA, Selvin J, Sabarathnam B, Lipton AP. Optimization and characterization of a new lipopeptide biosurfactant produced by marine Brevibacterium aureum MSA13 in solid state culture. Bioresour Technol. 2010;101(7):2389-96.

35. Chakravarthy B, Vijayasree J, Swathi V, Sudhira D, Maheswari U, Devi P. Screening and exploration of azo dye decolorizing actinomycetes from marine sediments. Int J Sci Eng Res. 2015;6(2):27-30.

36. Kügler JH, Roes-Hill L, Syldatk C, Hausmann R. Surfactants tailored by the class actinobacteria. Front Microbiol. 2015;6:212.

37. Senan RC, Abraham TE. Bioremediation of textile azo dyes by aerobic bacterial consortium aerobic degradation of selected azo dyes by bacterial consortium. Biodegradation. 2004;15(4):275-80.

38. Altaf A, Noor S, Sharif $\mathrm{QM}$, Najeebullah M. Different techniques recently used for the treatment of textile dyeing effluents: A review. J Chem Soc Pakistan. 2010;32(1):115-6.

39. Velmurugan S, Ravikumar R. Biodegradation and decolorization of reactive dye red ME4BL by Bacillus subtilis. Int J Env Bioremed Biodegrad. 2014;2(6):250-5.

40. Ponraj M, Gokila K, Zambare V. Bacterial decolorization of textile dye-Orange 3R. Int J Adv Biotechnol Res. 2011;2(1):168-77.

41. Dafale N, Rao NN, Meshram SU, Wate SR. Decolorization of azo dyes and simulated dye bath wastewater using acclimatized microbial consortiumbiostimulation and halo tolerance. Bioresour Technol. 2008;99(7):2552-8.

42. Pinheiro $\mathrm{HM}$, Touraud $\mathrm{E}$, Thomas $\mathrm{O}$. Aromatic amines from azo dye reduction: status review with emphasis on direct UV spectrophotometric detection in textile industry wastewaters. Dyes Pigm. 2004;61(2):121-39.

43. Bagewadi ZK, Vernekar AG, Patil AY, Limaye AA, Jain VM. Biodegradation of industrially important textile dyes by actinomycetes isolated from activated sludge. Biotechnol Bioinfo Bioeng. 2011;1(3):351-60.

44. Rekik H, Nadia ZJ, Bejar W, Kourdali S, Belhoul M, Hmidi M, et al. Characterization of a purified decolorizing detergent-stable peroxidase from Streptomyces griseosporeus SN9. Int J Biol Macromol. 2015;73:253-63.

45. Touioui SB, Jaouadi NZ, Boudjella H, Ferradji FZ, Belhoul M, Rekik H, et al. Purification and biochemical characterization of two detergent-stable serine alkaline proteases from Streptomyces sp. strain AH4. World J Microbiol Biotechnol. 2015;31(7):1079-92.

46. Elhoul MB, Jaouadi NZ, Rekik H, Bejar W, Touioui SB, Hmidi M, et al. A novel detergent-stable solvent-tolerant serine thiol alkaline protease from Streptomyces koyangensis TN650. Int J Biol Macromol. 2015;79:871-82. 
47. Garg SK, Tripathi M. Microbial strategies for discoloration and detoxification of azo dyes from textile effluents. Res J Microbiol.2017;12:1-19.

48. Desai JD. Microbial surfactants: Evaluation, types, production and future applications. J Sci Ind Res India. 1987;46:440-9.

49. Keller U, Lang M, Crnovcic I, Pfennig F, Schauwecker F. The actinomycin biosynthetic gene cluster of Streptomyces chrysomallus: A genetic hall of mirrors for synthesis of a molecule with mirror symmetry. J Bacteriol. 2010;192(10):2583-95

50. Raja A, Prabakarana P. Actinomycetes and drug-an overview. American J Drug Discov Develop. 2011;1(2):75-84.

51. Chaudhary HS, Soni B, Shrivastava AR, Shrivastava S. Diversity and versatility of actinomycetes and its role in antibiotic production. J Appl Pharmaceutical Sci. 2013;3(8):S83-94.

52. McGuire JM, Bunch RL, Anderson RC, Boaz HE, Flynn EH, Powell HM, et al. Ilotycin, a new antibiotic. Antibiotic Chemother. 1952;2:281-3.

53. Sobin BA, English AR, Celmer WD. PA 105, a new antibiotic. Antibiot Annu. 1954;55:827.

54. Albouy R, Duchesnay G, Eloy P, Pestel M, Ravina A, Rey M. A new French antibiotic: Spiramycin. Antibiotic Annu. 1955;3:223.

55. Oliynyk M, Stark CB, Bhatt A, Jones MA, Hughes-Thomas ZA, Wilkinson C. Analysis of the biosynthetic gene cluster for the polyether antibiotic monensin in Streptomyces cinnamonensis and evidence for the role of monB and monC genes in oxidative cyclization. Mol Microbiol. 2003;49(5):1179-90.

56. Xiao Y, Li S, Niu S, Ma L, Zhang G, Zhang H, et al. Characterization of tiacumicin B biosynthetic gene cluster affording diversified tiacumicin analogues and revealing a tailoring dihalogenase. J American Chem Soc. 2010;133(4):1092-105.

57. Floss HG, Yu TW. Rifamycin mode of action, resistance and biosynthesis. Chem Rev. 2005;105(2):621-32.

58. Mosaei H, Molodtsov V, Kepplinger B, Harbottle J, Moon CW, Jeeves RE. Mode of action of kanglemycin $A$, an ansamycin natural product that is active against rifampicin-resistant Mycobacterium tuberculosis. Mol Cell. 2018;72(2):263-74.

59. Finlay AC, Hobby GL, P'an SY, Regna PP, Routien JB, Seeley DB. Terramycin, a new antibiotic. Science. 1950;85-7.

60. Chopra I, Roberts M. Tetracycline antibiotics: mode of action, applications, molecular biology and epidemiology of bacterial resistance. Microbiol Mol Biol Rev. 2001;65(2):232-60.

61. Preud'homme J, Tarridec P, Belloc A. 90. Isolation, characterization and identification of the components of pristinamycin. Bulletin Soc Chim Fr. 1968;2:585-91.

62. Chen C, Song F, Wang Q, Abdel-Mageed WM, Guo H, Fu C, et al. A marinederived Streptomyces sp. MS449 produces high yield of actinomycin X 2 and actinomycin D with potent anti-tuberculosis activity. Appl Microbiol Biotechnol. 2012;95(4):919-27.

63. Alharbi NS. Novel bioactive molecules from marine actinomycetes. Biosci Biotechnol Res Asia. 2016;13(4):1905-27.
64. Jakubiec-Krzesniak K, Rajnisz-Mateusiak A, Guspiel A, Ziemska J, Solecka J. Secondary metabolites of actinomycetes and their antibacterial, antifungal and antiviral properties. Pol J Microbiol. 2018;67(3):259-72.

65. Majumdar P, Wu H, Tipton P, Glaser R. Oxanosine is a substrate of adenosine deaminase. Implications for the quest for a toxicological marker for nitrosation activity. Chem Res Toxicol. 2005;18(12):1830-41.

66. Jakubiec-Krzesniak K, Rajnisz-Mateusiak A, Guspiel A, Ziemska J, Solecka J. Secondary metabolites of actinomycetes and their antibacterial, antifungal and antiviral properties. Pol J Microbiol. 2018;67(3):259-72.

67. Messaoudi O, Sudarman E, Bendahou M, Jansen R, Stadler M, Wink J. Kenalactams A-E, Polyene macrolactams isolated from Nocardiopsis CG3. J Nat Prod. 2019;82(5):1081-8.

68. Hazen EL, Brown R. Fungicidin, an antibiotic produced by a soil actinomycete. Pro Soc Exp Biol Med. 1951;76(1):93-7.

69. Brautaset T, Sletta H, Nedal A, Borgos SE, Degnes KF, Bakke I. Improved antifungal polyene macrolides via engineering of the nystatin biosynthetic genes in Streptomyces noursei. Chem Biol. 2008;15(11):1198-206.

70. Dutcher JD. The discovery and development of amphotericin B. Chest. 1968;54:296-8.

71. Struyk AP, Drost G, Haisvisz JM, Eek TV, Hoogerheide JC. Pimaricin, a new antifungal antibiotic. Antibiot Annu. 1958;5:878-85.

72. Lakshmipathy TD, Prasad AA, Kannabiran K. Production of biosurfactant and heavy metal resistance activity of Streptomyces sp. VITDDK3-a novel halo tolerant actinomycetes isolated from saltpan soil. Biol Res. 2010;4(2):108-15.

73. Purushe S, Prakash D, Nawani NN, Dhakephalkar P, Kapadnis B. Biocatalytic potential of an alkalophilic and thermophilic dextranase as a remedial measure for dextran removal during sugar manufacture. Bioresour Technol. 2012;115:2-7.

74. Chen CY, Huang YC, Wei CM, Meng M, Liu WH, Yang CH. Properties of the newly isolated extracellular thermo-alkali-stable laccase from thermophilic actinomycetes, Thermobifida fusca and its application in dye intermediates oxidation. AMB Express. 2013;3(1):49.

75. Wu CY, Chen N, Li H, Li QF. Kocuria rosea HN01, a newly alkaliphilic humusreducing bacterium isolated from cassava dreg compost. J Soil Sediment. 2014;14(2):423-31.

76. Habbeche A, Saoudi B, Jaouadi B, Haberra S, Kerouaz B, Boudelaa M. Purification and biochemical characterization of a detergent-stable keratinase from a newly thermophilic actinomycete Actinomadura keratinilytica strain Cpt29 isolated from poultry compost. J Biosci and Bioeng. 2014;117(4):413-21.

77. Chakraborty S, Ghosh M, Chakraborti S, Jana S, Sen KK, Kokare C, et al. Biosurfactant produced from Actinomycetes nocardiopsis A17: characterization and its biological evaluation. Int $\mathrm{J}$ Biol Macromol. 2015;79:405-12.

78. Kumar AK. UV mutagenesis treatment for improved production of endoglucanase and $\beta$-glucosidase from newly isolated thermotolerant actinomycetes, Streptomyces griseoaurantiacus. Bioresour Bioprocess. 2015;2:22.

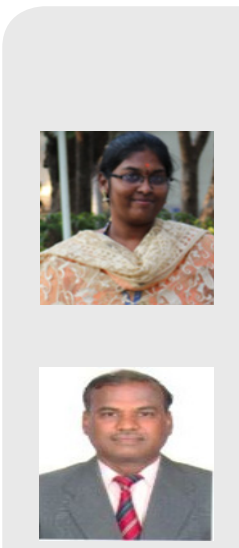

About Authors

Ms. Bhakyashree $\mathbf{K}$ is currently pursuing Ph.D. in the Department of Biomedical Sciences, School of Biosciences and Technology, Vellore Institute of Technology (Deemed to be University), Vellore. Her areas of research include Actinomycetes metabolites against drug resistant MRSA pathogens.

Prof. Kannabiran K, Senior Professor in the Department of Biomedical Sciences, School of Biosciences and Technology, Vellore Institute of Technology (Deemed to be University), Vellore. His areas of research interest includes bioactivity of terrestrial and marine Actinomycetes secondary metabolites and microbiology 


\section{PICTORIAL ABSTRACT}

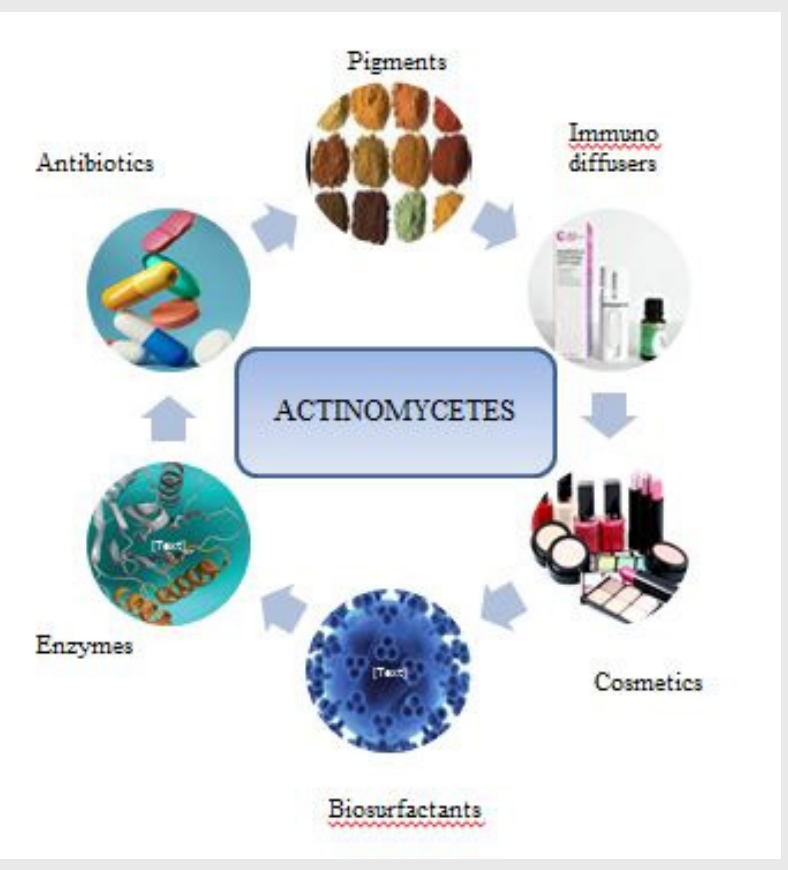

\section{SUMMARY}

- Actinobacteria plays a vital role in pharmaceutical and biotechnological industries by producing many natural compounds such as antibiotics, enzymes, natural pigments, biosurfactants and enzyme inhibitors.

- Dye degradation by these actinobacteria was found to be more effective when compared to the other degradation techniques.

- Metabolites derived from actinomycetes play a significant role in various cosmetic industries.

- This review briefly discusses the pharmaceutical as well as biotechnological importance of actinobacterial products.

Cite this article: Bhakyashree K, Kannabiran K. Pharmaceutical and Biotechnological Importance of Actinobacterial Products. Indian J of Pharmaceutical Education and Research. 2020;54(4):858-64. 